\title{
Women ODs in Quebec: An integral part of Montreal's history and of its centennial celebration
}

\author{
BY ETTY BITTON, OD, MSC, FAAO
}

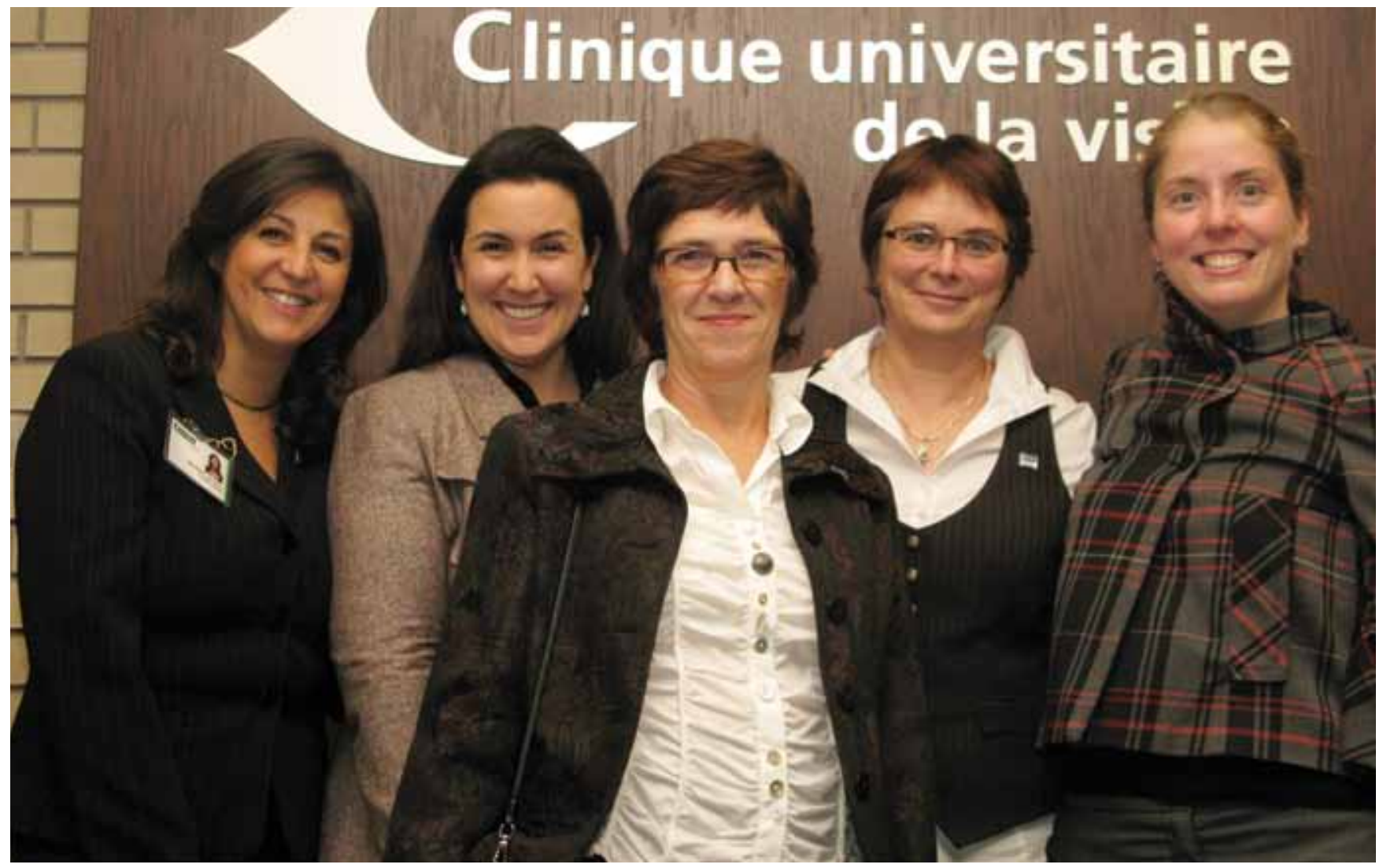

Faculty members: left to right, Dr. Etty Bitton (OD, MSc, FAAO, associate professor and Director of Clinical Externships) Dr. Julie-Andrée Marinier (OD, MSc, assistant professor), Julie-Anne Couturier (BSc.Ed., MA, associate professor), Dr. Danielle DeGuise (OD, MSc, associate professor), Dr. Julie Brulé (OD, MSc, FAAO, assistant professor)

Whe École d'optométrie, Université de Montréal (School of Optometry at the University of Montreal - UM), has reached a momentous milestone in 2010 — its centennial celebration! The École d'optométrie is the only francophone optometry school in the world to offer an OD degree. One of only two optometry schools in Canada, the UM graduates 40 students per year and many remain in Quebec to service the ever-growing population. This exceptional year will be full of unique events highlighting this momentous milestone which began with the launch of the centennial celebrations this past January with key community and professional leaders. A special continuing education event is scheduled for May, which will update the attendees on the latest clinical and basic science research performed at 


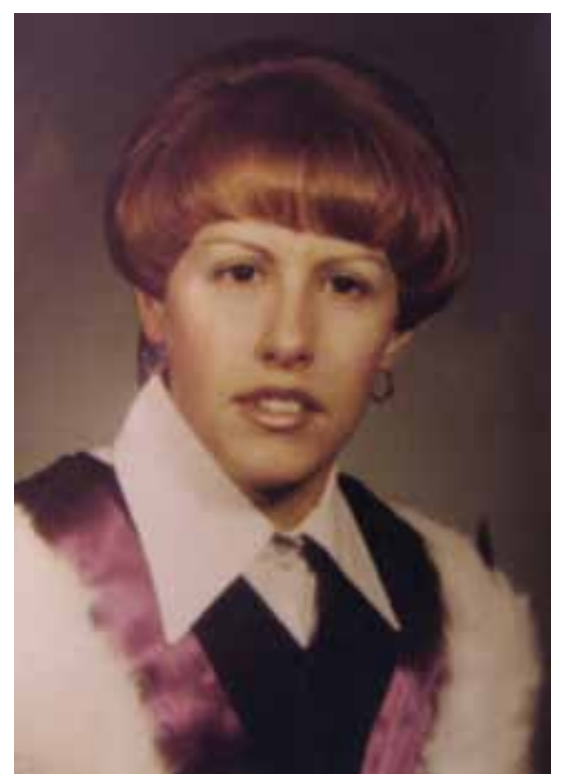

Dr. Nicole Lapierre (first female faculty member, this picture was from 1979)

the school. The weekend will culminate with a gala event where alumni are encouraged, actually challenged, to have as many of their classmates in attendance. There are presently 1284 registered optometrists ${ }^{1}$ in Quebec, most of whom are alumni of the school.

One amazing piece of trivia is that the percentage of women at the École d'optométrie has been well over $50 \%$ for the past several years. In fact, upon further investigation uncovering the history of the school and the impact of women on the program, some interesting facts have come to the surface. In the early years of optics training, the first records of women in the program included U. Crandell (1915), E. Cantara (1918) and J. D'Osennens (1927). As of 1929 , the program evolved from a technical training program to a bachelor program, whereby the first female graduate of the optometry program, then a 3-year program, was Dr. Pauline Caron, who graduated in 1938. Women in the program were very sporadic in these early years. A steady female presence was only seen as of 1960 and evolved throughout that decade. The female contingency really took a stronghold in the mid 1970's and by 1978 it was over $50 \%$ of the class, a level that has remained ever since. The program continues to flourish with the expanding scope of practice and is now a total of five years, including a one year pre-optometry curriculum. For the 2013 graduating class, $80 \%$ are female, the second highest percentage amongst all the North American optometry schools. ${ }^{2}$ Among the 1284 registered optometrists in Quebec, 817 are women comprising $63 \%$ of the practicing eye care professionals. $^{2}$

The first female faculty member was Dr. Nicole Lapierre, who joined the faculty as a lecturer in 1976 and remained for over 10 years. Since then, many more women have joined the faculty as clinical supervisors, lecturers and full time tenured faculty. Dr. Danielle DeGuise, presently the chief of the binocular vision service, has been on the faculty the longest, with over 22 years as an educator.

Dr. Angela Kothe and Dr. Hélène Kergoat were the first female faculty members to hold $\mathrm{PhD}$ degrees. Dr. Kergoat was also the first female UM alumni to receive her

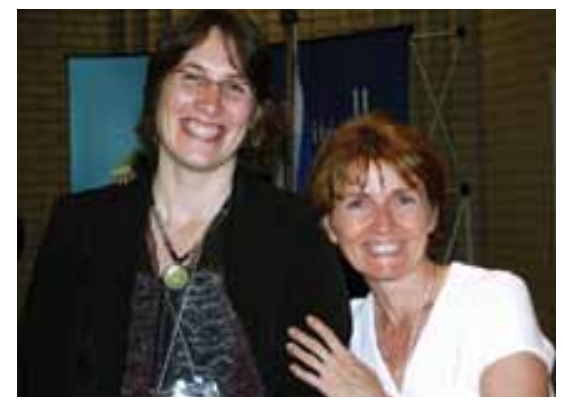

Dr. Elvire Vaucher (PhD, associate professor) Dr. Hélène Kergoat (OD, MSc, PhD, FAAO, full professor)

Fellow from the American Academy of Optometry (AAO) in 1991 and was the first to become a research fellow in the area of geriatric care, a topic that remains the focus of her research today. Dr. Linda Trick was the first female Clinic Director in 1993 and Dr. Etty Bitton was the first Externship Director in 1994 and remains in that function today. So far, there has been no woman Director/Dean of the school — but the future is promising.

Women have definitely played a pivotal role in the history of optometry at the UM School of Optometry and they have good reason to celebrate. The next 100 years are sure to have many firsts for women as well. Happy centennial!

\section{References}

1. Quebec Order of Optometrists, communication January 15, 2010

2. Class of 2013 Draws more women than men. Women in Optometry. 2009; Nov:7 